\title{
INFLUENCE OF THE TOTAL POWER OF THE HEART RATE VARIABILITY SPECTRUM ON THE SPECTRAL PARAMETERS DISTRIBUTION IN PATIENTS WITH ARTERIAL HYPERTENSION IN A PACED BREATHING TEST
}

Golubkina E. O., Yabluchansky M. I.

V. N. Karazin Kharkiv National University, Kharkiv, Ukraine

To determine the effect of the total power (TP) of the heart rate variability (HRV) spectrum on the distribution of high, low and very low frequency waves, 40 patients with arterial hypertension (AH) at the age of $58 \pm 9$ years were divided into 5 groups according to the degree of TP decrease in the initial stage of the test: $1^{\text {st }}$ - more than $3000 \mathrm{~ms}^{2} ; 2 \mathrm{nd}-3000-2000 \mathrm{~ms}^{2} ; 3 \mathrm{rd}-2000-1000 \mathrm{~ms}^{2} ; 4$ th $-1000-500 \mathrm{~ms}^{2}$; 5th - less than $500 \mathrm{~ms}^{2}$. To assess HRV parameters in each group, 3 stages of the paced breathing test with a double (light and sound) metronome were evaluated; the hardware and software complex «Cardiolab» («HAIMedica») was used. The distribution of the parameters was estimated taking into account the median, 25 and 75 quartiles. To estimate the differences between the statistical samples, the nonparametric Mann-Whitney U-test was used, as well as the Craskell-Wallis criterion. Statistically significant differences were considered between the data at a value of $p<0.05$. It was found that the greater is the degree of TP reduction, the more significant is the autonomic imbalance, as well as the decrease in the influence of paced breathing on the regulation of the heart rhythm; at TP values below $1000 \mathrm{~ms}^{2}$ not only the parasympathetic component decrease is observed, but also the transition from sympathicotonia to the neurohumoral factors prevalence.

KEY WORDS: arterial hypertension, heart rate variability, paced breathing

\section{ВПЛИВ ЗАГАЛЬНОӤ ПОТУЖНОСТІ СПЕКТРУ ВАРІАБЕЛЬНОСТІ СЕРЦЕВОГО РИТМУ НА РОЗПОДІЛ СПЕКТРАЛЬНИХ ПОКАЗНИКІВ У ПАЦІЕНТІВ 3 АРТЕРІАЛЬНОЮ ГІПЕРТЕНЗІЕЮ В ПРОБІ 3 МЕТРОНОМІЗОВАНИМ ДИХАННЯМ}

Голубкіна Є. О., Яблучанський М. І.

Харківський національний університет імені В. Н. Каразіна, м. Харків, Україна

Для визначення впливу загальної потужності (ТР) спектра варіабельності серцевого ритму (ВСР) на розподіл хвиль високої, низької і дуже низької частоти 40 пацієнтів з артеріальною гіпертензією (АГ) у віці $58 \pm 9$ років були розділені на 5 груп за ступенями зниження ТР на фоновому етапі проби:

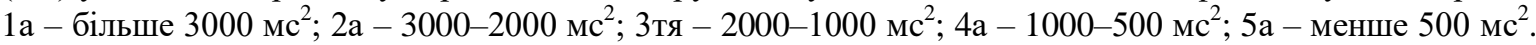
Для оцінки показників ВСР в кожній групі оцінювалися 3 етапи проби з метрономізованим диханням 3 подвійним (світловим і звуковим) метрономом; використовувався програмно-апаратний комплекс «Кардіолаб» («ХАІ-Медика»). Розподіл показників оцінювався 3 урахуванням медіани, 25 і 75 квартилей. Для оцінки відмінностей між вибірками використовувалися непараметрический U-критерій Манна-Уїтні, а також критерій Краскелла-Уолесса. Статистично значущими вважалися відмінності між даними при значенні $\mathrm{p}<0,05$. Було встановлено, що чим більше ступінь зниження ТР, тим більш значущим $є$ автономний дисбаланс, а також зниження впливу метрономізаціі дихання на регуляцію серцевого ритму; при значеннях ТР нижче 1000 мс $^{2}$ спостерігається не тільки падіння потужності парасимпатичної ланки, а й перехід від симпатикотонії до переважання нейрогуморальних факторів.

КЛЮчОВІ СЛОВА: артеріальна гіпертензія, варіабельність серцевого ритму, метрономізоване дихання 


\section{ВЛИЯНИЕ ОБЩЕЙ МОЩНОСТИ СПЕКТРА ВАРИАБЕЛЬНОСТИ СЕРДЕЧНОГО РИТМА НА РАСПРЕДЕЛЕНИЕ СПЕКТРАЛЬНЫХ ПОКАЗАТЕЛЕЙ У ПАЦИЕНТОВ С АРТЕРИАЛЬНОЙ ГИПЕРТЕНЗИЕЙ В ПРОБЕ С МЕТРОНОМИЗИРОВАННЫМ ДЫХАНИЕМ}

Голубкина Е. А., Яблучанский Н. И.

Харьковский национальный университет имени В. Н. Каразина, г. Харьков, Украина

Для определения влияния общей мощности спектра ВСР (ТР) на распределение волн высокой, низкой и очень низкой частоты 40 пациентов с артериальной гипертензией (АГ) в возрасте $58 \pm 9$ лет были разделены на 5 групп по степеням снижения ТР на фоновом этапе пробы: 1 я - более $3000 \mathrm{mc}^{2} ; 2$ я

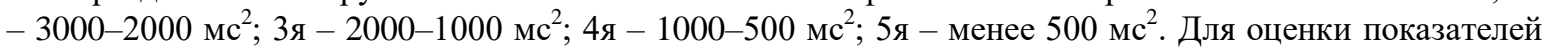
ВСР в каждой группе оценивались 3 этапа пробы с метрономизированным дыханием с двойным (световым и звуковым) метрономом; использовался программно-аппаратный комплекс «Кардиолаб» («ХАИ-Медика»). Распределение показателей оценивалось с учетом медианы, 25 и 75 квартилей. Для оценки различий между выборками использовались непараметрический U-критерий Манна-Уитни, а также критерий Краскелла-Уолесса. Статистически значимыми считались различия между данными при значении $\mathrm{p}<0,05$. Было установлено, что чем больше степень снижения ТР, тем более значимым является автономный дисбаланс, а также снижение влияния метрономизации дыхания на регуляцию сердечного ритма; при значениях ТР ниже 1000 мс $^{2}$ наблюдается не только падение мощности парасимпатического звена, но и переход от симпатикотонии к превалированию нейрогуморальных факторов.

КЛЮЧЕВЫЕ СЛОВА: артериальная гипертензия, вариабельность сердечного ритма, метрономизированное дыхание

\section{INTRODUCTION}

Frequency analysis of heart rate variability (HRV) in patients with arterial hypertension (AH) provides ample opportunities to study the functional features of cardiac activity regulation, the determination of sympathovagal relationship, and the influence of neurohumoral factors on the pathological links of arterial hypertension [1-2]. The paced breathing test allows study the functional state of the cardiovascular system dynamically, which is especially important for diagnostics and monitoring of patients with $\mathrm{AH}$ [3-4].

One of the most important components of HRV is the total power of its spectrum (TP), which includes the full spectrum of heart rate variability frequencies, reflecting the total vegetative (autonomous) effect on the regulation of cardiac activity. According to the clinical protocols of the European Cardiology Society [5], the frequency range for TP is up to $0.4 \mathrm{~Hz}$, and the normal values are defined as $3466 \pm 1018 \mathrm{~ms}^{2}$. The fluctuations of this parameter reflect the general functional state and adaptive capabilities of the organism, being an indicator of pathological changes and regulatory failures.

According to the studies [5-8] in patients with arterial hypertension, [the total power of the spectrum] TP is usually reduced, as well as the redistribution of HRV components with an increase in sympathetic and neurohumoral influences, mainly due to a decrease in the parasympathetic component of the HRV spectrum. However, studies aimed at studying the effect of reducing the total power of the HRV spectrum on the distribution of spectral components and the degree of aggravation of cardiac regulation imbalance in hypertension have not been performed.

The aim of this article is to determine the severity of sympathovagal imbalance, as well as changes in the ratio of frequency HRV parameters depending on the degree of decrease in $\mathrm{TP}$ in patients with essential arterial hypertension in a paced breathing test.

\section{MATERIALS AND METHODS}

40 patients (18 men, 22 women) with essential hypertension aged $58 \pm 9$ years were examined including: patients with $\mathrm{AH} 1$ degree - 14 (35\%), AH 2 degrees - 21 (52.5\%) and $\mathrm{AH} 3$ degrees - $5(1.25 \%)$ respectively; patients with stage I $-7(17.5 \%)$, stage II - 33 $(82.5 \%)$; the average duration of arterial hypetension $-6 \pm 5$ years. The newly diagnosed $\mathrm{AH}$ was detected in 1 patient $(2.5 \%)$.

Inclusion criteria: grade 1-3 arterial hypertension, stage I-II with stable angina pectoris IIII FC, chronic heart failure I-II stage I FC. 
Exclusion criteria: acute myocardial infarction, unstable angina, chronic heart failure IV FC, implanted pacemakers, acquired heart valve defects, rhythm disturbances, endocrine diseases (diabetes, thyrotoxicosis, etc.), exacerbation of somatic diseases, stroke, acute hypertensive encephalopathy, vascular dementia.

The blood pressure was measured with a Microlife BP AG1-20 tonometer according to Korotkov's method. Clinical diagnosis of hypertension was made in accordance with the recommendations of the Ukrainian Association of Cardiology [9]. Calculation of HRV parameters was made using the software «Cardiolab» («HAI-Medica»).

Methods of HRV study: a test with paced (metronomized) breathing with a double (light and sound) metronome. Test conditions: test was performed in the morning hours (from 9.00 to 12.00 in a separate room with a room temperature of $20-22^{\circ} \mathrm{C}$ ); before the test, patients abstained from smoking, drinking coffee and alcoholic beverages.

Protocol for paced breathing test:

1. Initial stage at rest -5 minutes;

2. Deep controlled breathing with a frequency of 6 times / min -5 minutes;

3 . Recording after breathing (recovery) 5 minutes.

In the first initial resting stage the patients were maintained at rest breathing freely in familiar to them rhythm and depth of breathing for 5 minutes to ensure that a true resting HRV values were obtained; in the second stage of paced breathing patients were instructed to perform breathing in breathing rate of 6 times per minute with additional control of visual and sound metronome for 5 minutes; in the third final resting stage the patients were breathing in a free manner for 5 minutes.

The results of the test were interpreted on the basis of international standards (protocols of the European Cardiological Society) [10]. The values of TP (total power of the HRV spectrum), low frequency wave LF (0.04$0.15 \mathrm{~Hz}$ ), very low frequency wave VLF $(<0.04 \mathrm{~Hz})$, high frequency wave HF $(0.15-$ $0.4 \mathrm{~Hz}$ ), and LF / HF index the power of lowfrequency waves to the power of highfrequency waves). These parameters were estimated in absolute and normalized units.

Depending on the degree of decrease in the TP at the initial stage of the test, the patients were divided into 5 groups: 1 - more than $3000 \mathrm{~ms}^{2}$ was detected in 3 patients $(7.5 \%) ; 2-$ $3000-2000 \mathrm{~ms}^{2}$ in 3 patients $(7.5 \%)$; 3rd $2000-1000 \mathrm{~ms}^{2}$ in 12 patients $(30 \%)$; 4 th $1000-500 \mathrm{~ms}^{2}$ in 13 patients $(32.5 \%)$; 5 th less than $500 \mathrm{~ms}^{2}$ in 10 patients $(25 \%)$. In each group, all 3 stages of the test were evaluated.

During the statistical processing of data Microsoft Excel 7.0 software was used. In each group, the median, 25 and 75 quartiles were determined to evaluate the distribution of the parameters. To estimate the differences between the test samples, the nonparametric MannWhitney U test was used, as well as the Craskell-Wallis criterion. Statistically signifycant differences were considered between the data at a value of $p<0.05$.

\section{RESULTS AND DISCUSSION}

The results of the distribution of spectral HRV parameters at different levels of TP reduction in patients with arterial hypertension are presented in table 1.

In the first group of patients, low-frequency influences prevailed in the initial stage of the test ( $\mathrm{p}<0.01)$, and LF / HF values indicated a pronounced sympathicotonia (LF/ HF-6.18 $[3.6,6.9])$. At the same time, the contribution of low-frequency influences at this stage in groups 2, 3, 4 and 5 was less pronounced mainly due to the prevalence of waves of very low frequency (see Fig. 1). The HF parameter at the initial stage was characterized by decreased values in all study groups, which indicates the limitation of the parasympathetic component in the regulation of the heart rhythm $(\mathrm{p}<0.01)$. 
Spectral HRV parameters depending on the TP decrease in the paced breathing test

\begin{tabular}{|c|c|c|c|}
\hline $\begin{array}{l}\text { Spectral HRV } \\
\text { parameters }\end{array}$ & Initial stage & Paced breathing stage & Resting stage \\
\hline \multicolumn{4}{|c|}{ Group 1. TP $>3000$} \\
\hline $\mathrm{LF}, \mathrm{ms}$ & $2075[1754 ; 2528]^{*}$ & $372[303 ; 415.5]$ & $1587[1108 ; 2639]$ \\
\hline VLF, ms & $1479[1383 ; 2416]$ & $1000[634 ; 1075]$ & $2073[1171 ; 2385]$ \\
\hline $\mathrm{HF}, \mathrm{ms}$ & $272[252 ; 1557]$ & $3476[2922 ; 8200]$ & $277[193 ; 1272]$ \\
\hline $\mathrm{LF} / \mathrm{HF}$ & $6.18[3.6 ; 6.9]$ & $0.1[0.07 ; 0.105]$ & $5.73[3.68 ; 5.7]$ \\
\hline \multicolumn{4}{|c|}{ Group 2. TP 3000-2000 } \\
\hline $\mathrm{LF}, \mathrm{ms}$ & $731[622.5 ; 829.3]$ & $153[95.3 ; 483]$ & $574[331.5 ; 793]$ \\
\hline VLF, ms & $992[930.3 ; 1151]$ & $376[150 ; 631.5]$ & $686[549.5 ; 1012]$ \\
\hline $\mathrm{HF}, \mathrm{ms}$ & $415[349.5 ; 438.3]$ & $1567[875 ; 4301]$ & $184[143.2 ; 344]$ \\
\hline $\mathrm{LF} / \mathrm{HF}$ & $2.01[1.76 ; 2.6]$ & $0.11[0.105 ; 0.11]$ & $2.3[1.6 ; 3.33]$ \\
\hline \multicolumn{4}{|c|}{ Group 3. TP 2000-1000 } \\
\hline $\mathrm{LF}, \mathrm{ms}$ & $312[256.8 ; 435]^{*}$ & $220[156.3 ; 412.3]^{*}$ & $296[211.3 ; 600]^{* *}$ \\
\hline VLF, ms & $614[538.8 ; 912]^{*}$ & $508[328.3 ; 598.5]$ & $614[539 ; 1053]^{*}$ \\
\hline $\mathrm{HF}, \mathrm{ms}$ & $203[122.3 ; 246.8]^{*}$ & $2514[1193 ; 4403]^{*}$ & $203[108 ; 237.3]$ \\
\hline $\mathrm{LF} / \mathrm{HF}$ & $2.8[1.14 ; 3.12]$ & $0.13[0.08 ; 0.2]$ & $2.7[1.09 ; 3.1]$ \\
\hline \multicolumn{4}{|c|}{ Group 4. TP 1000-500 } \\
\hline $\mathrm{LF}, \mathrm{ms}$ & $136[109 ; 195]^{*}$ & $112[76 ; 144]^{*}$ & $163[122 ; 361]^{* *}$ \\
\hline VLF, ms & $331[232 ; 404]^{*}$ & $346[136 ; 534]$ & $440[280 ; 525]^{*}$ \\
\hline $\mathrm{HF}, \mathrm{ms}$ & $99[37 ; 113]^{*}$ & $553[325 ; 1352]^{*}$ & $93[44 ; 160]$ \\
\hline $\mathrm{LF} / \mathrm{HF}$ & $1.97[0.88 ; 2.97]$ & $0.16[0.13 ; 0.26]$ & $1.95[1.39 ; 3.39]$ \\
\hline \multicolumn{4}{|c|}{$\begin{array}{r}\text { Group 5. TP }<500 \\
\end{array}$} \\
\hline $\mathrm{LF}, \mathrm{ms}$ & $86.5[61.75 ; 105.8]^{*}$ & $74.5[37.3 ; 150]^{*}$ & $156[96 ; 241.3]^{* *}$ \\
\hline VLF, ms & $154.5[123.8 ; 201]^{*}$ & $263[160 ; 477.5]$ & $360.5[290 ; 484.8]^{*}$ \\
\hline $\mathrm{HF}, \mathrm{ms}$ & $59.5[22.5 ; 112.3]^{*}$ & $479[335.8 ; 890]^{*}$ & $45[29.5 ; 158.3]$ \\
\hline $\mathrm{LF} / \mathrm{HF}$ & $1.63[0.97 ; 3]$ & $0.15[0.09 ; 0.22]$ & $2.38[1.8 ; 2.9]$ \\
\hline
\end{tabular}

Note. $* p<0.01, * * p<0.05$.

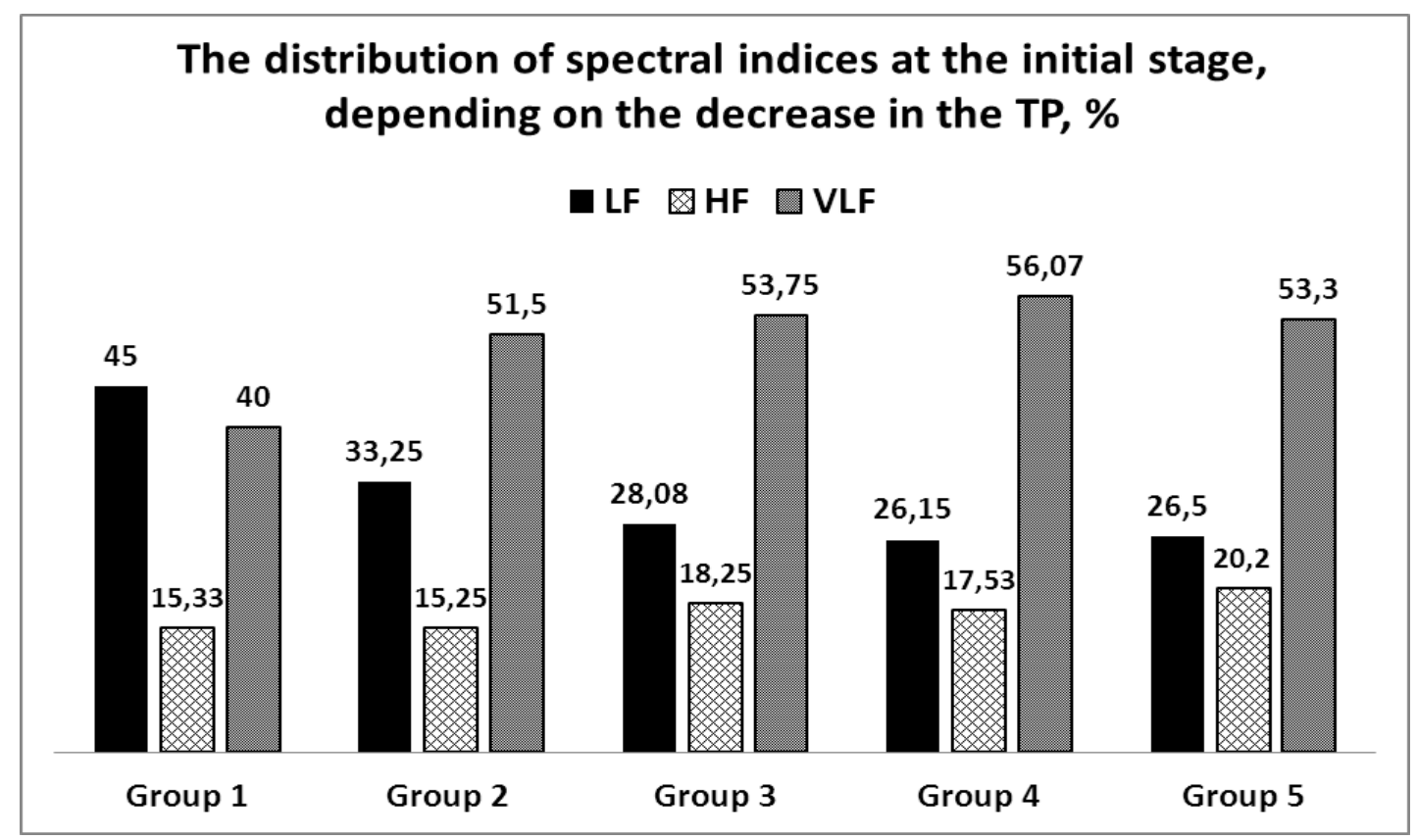

Fig. 1. Distribution of spectral parameters at the initial stage of the paced breathing test, depending on the decrease in TP, \% 
At the stage of metronomized breathing, high frequency waves dominated in all groups, however the intensity of the parasympathetic response to the paced breathing was not the same depending on the degree of TP decrease: thus, the maximum HF values were observed in group 1, while the lowest values were recorded in group 4 and group $5(\mathrm{p}<0.01)$. As a percentage, $\mathrm{HF}$ in the paced breathing stage was $81.33 \%$ in the first group, progressively decreasing in groups 2, 3, and 4; in group 5, the share of high-frequency influences was the smallest and was determined as $55.9 \%$; Thus, the difference between the fraction of highfrequency waves in the first and fifth group was $25.4 \%$ (Fig. 2).

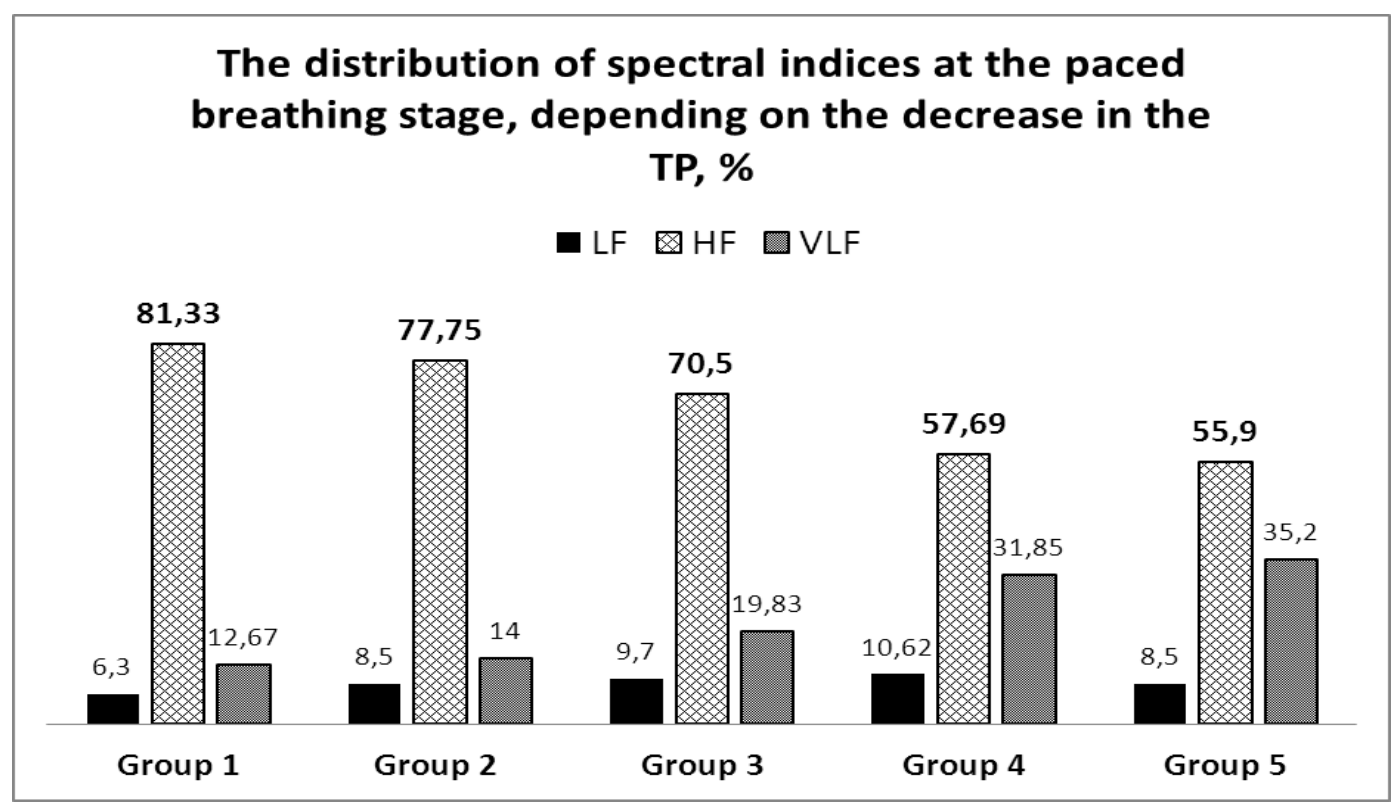

Fig. 2. Distribution of spectral indices at the stage of paced breathing, depending on the degree of decrease in TP, \%

Also at this stage, along with the weakening of the parasympathetic response, there was a shift towards increasing neurohumoral influences in groups with lower TP values.

At the resting stage in group 1 low frequency waves prevailed, however sympathicotonia was less pronounced (LF / HF $5.73[3.68,5.7])$, mainly due to the amplification of VLF waves. The distribution of spectral indices in the remaining groups was characterized by the neurohumoral level of regulation of the heart rhythm: the proportion of very low frequency waves in these groups exceeded $50 \%$, while the low frequency indices were slightly lower compared to the initial stage. The HF values showed no gain at the resting stage in all study groups, a slight increase was observed in the second and fourth groups, and in group 5, characterized by the most pronounced neurohumoral effects (VLF - 59, $3 \%$ ), a decrease in the proportion of HF waves (Fig. 3). 


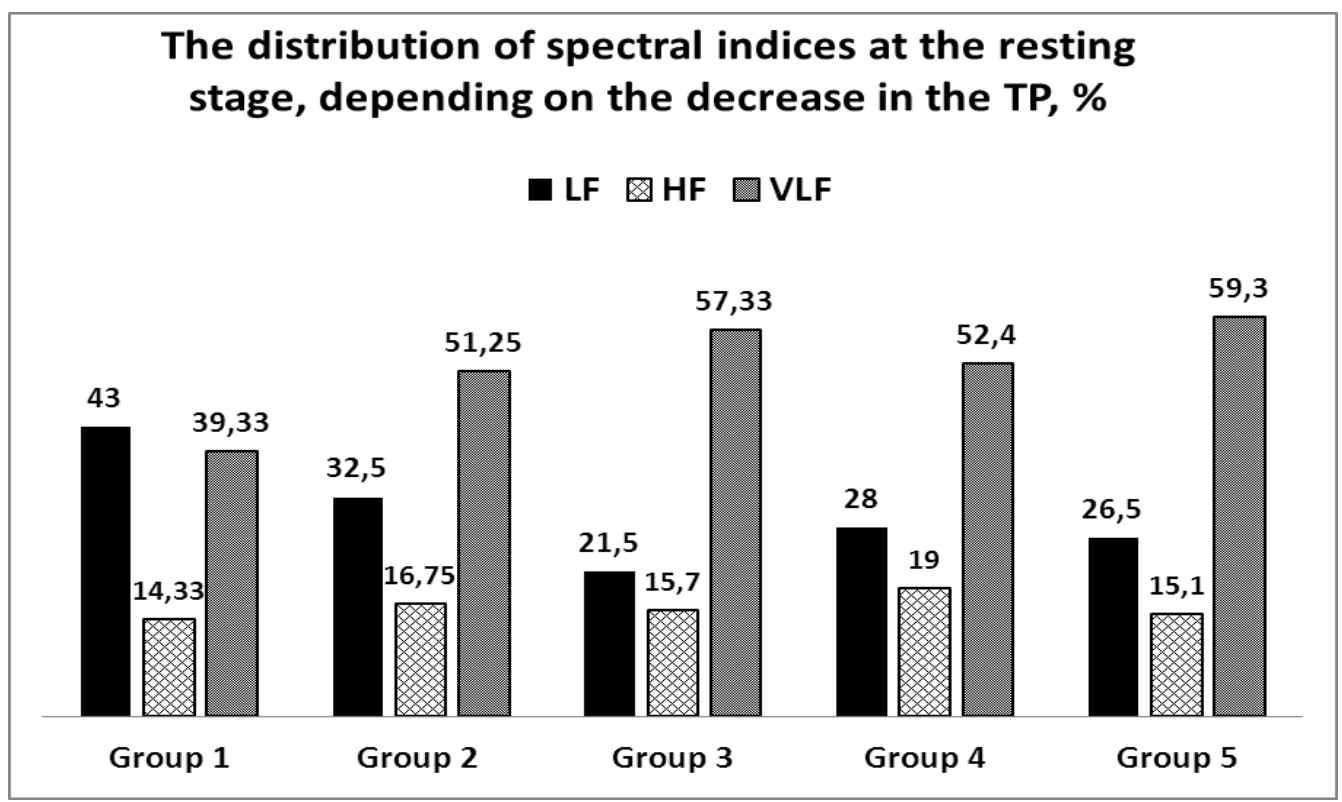

Fig. 3. Distribution of spectral parameters at the resting stage of paced breathing test, depending on the decrease in TP, \%

The obtained data indicate that in patients with arterial hypertension, low and very low frequency waves play a leading role in the regulation of the heart rhythm, which is also confirmed by studies [3,5-8]. At the same time $[6-8,11]$ there is a limitation of parasympathetic influences on management of cardiac activity in patients with arterial hypertension. The results of our studies confirm these data. In addition, it was found that the more the level of total power of the spectrum decreases, the less pronounced is the parasympathetic response to the paced breathing. For example, at TP values of $2000-3000 \mathrm{~ms}^{2}$ or more, the contribution of high-frequency waves was significant (77$81 \%$ ), while at values of the total power less than $1000 \mathrm{~ms}^{2}$, the effect of metronomized breathing on the regulation of the heart rate decreased significantly with the values of HF reflecting that (55-57\%). Simultaneously with limiting the proportion of highfrequency waves in the HRV spectrum, with a decrease in total power, there was a transition from the prevalence of sympathetic HRV components to neurohumoral mechanisms of heart rhythm regulation. Consequently, the degree of reduction in TP is an important factor associated with aggravation of autonomous imbalance and redistribution of spectral HRV parameters, which affects the prognosis and course of arterial hypertension.
Thus, research in this field is a valuable addition to the diagnostics and dynamic monitoring of patients with hypertension and is of interest for further study.

\section{CONCLUSION}

In patients with arterial hypertension, there is a tendency of decrease in the total power of the HRV spectrum, thus reflecting the decreased functional capacity of heart rhythm regulation.

The lower the degree of TP, the more significant is the disturbance of HRV regulation with a decrease in the parasympathetic component of the heart rate variability spectrum and the dominant influence of sympathetic and neurohumoral factors.

The influence of the paced breathing on the heart rhythm regulation falls depending on the decrease in the total power of the HRV spectrum: at TP values below $1000 \mathrm{~ms}^{2}$ not only the parasympathetic component decrease is observed, but also the transition from sympathotonia to the neurohumoral factors prevalence.

Decrease in TP can be considered as an indicator of aggravation of autonomic and neurohumoral regulation.

The paced breathing test allows determine the basic level of cardiac activity regulation and dynamic disruptions in the distribution of HRV components in the metronomized breathing, as well as the possibilities for 
restoring the regulatory balance of heart rate variability, which is especially important in the examination of patients with arterial hypertension.

\section{PROSPECTS FOR FUTURE STUDIES}

In the future, the study of neurohumoral factors of HRV is promising, as well as the distribution of spectral indices of cardiac rhythm variability at the stages of $\mathrm{AH}$ therapy.

\section{REFERENCES}

1. Yabluchanskyy N. Y., Varyabel'nost' serdechnoho rytma v pomoshch' praktycheskomu vrachu. Dlya nastoyashchykh vrachey. / N. Y. Yabluchanskyy, A. V. Martynenko - Khar'kov, $2010-131$ p.

2. Da Silva Natália Turri. Hypertension and Autonomic Control/ Natália Turri da Silva, Thais Roque Giacon [et al.] // American Journal of Medical Sciences and Medicine. - 2014. - Vol. 2, No. 2. - p. 48-53.

3. Golubkina E. O. Assessment of changes in the distribution ratios of ultra-low-frequency, low-frequency and high-frequency components of heart rate variability during the paced breathing test in patients with arterial hypertension / E. O. Golubkina, O. O. Golubkina // Vísnik Kharkívs'kogo natsíonal'nogo uníversitetu ím. V. N. Karazína. - 2016. - Issue 31. - p. 10-17.

4. Oyeleye L. Dynamic changes in spectral heart rate variability parameters in paced breathing test in patient with uncontrolled arterial hypertension and polymorbidity / L. Oyeleye, M. Saja [et al.] // Vísnik Kharkívs'kogo natsíonal'nogo uníversitetu ím. V. N. Karazína. - 2016. - Issue 32. - p. 73-78.

5. Gorantla S. G. B. K. Heart rate variability parameters in patients with arterial hypertension in dependence on the type of daily blood pressure profile / S. G. B. K. Gorantla, O. V. Petrenko, O. V. Martynenko // Vísnik Kharkívs'kogo natsíonal'nogo uníversitetu ím. V. N. Karazína. - 2017. - Issue 33. - p. 17-22.

6. Lutfi Mohamed Faisal. Effect of blood pressure on heart rate variability / Mohamed Faisal Lutfi, Mohamed Yosif Sukkar // Khartoum Medical Journal. - 2011. - Vol. 04, Is. 1 - p. 548-553.

7. Cardiac autonomic control in adolescents with primary hypertension. [electronic resource]/ [Havlíceková Z.] // Eur. J. Med. Res. - 2009. - Access to resource: https://www.ncbi.nlm.nih.gov/pmc/articles/PMC3521333/.

8. Natarajan Nirmala. A study on analysis of Heart Rate Variability in hypertensive individuals / Nirmala Natarajan, Arun Kumar Balakrishnan [et al.] // International Journal of Biomedical and Advance Research. - 2014. - Is. 5. - p. 109-111.

9. Sertsevo-sudinni zahvoryuvannya. Klasifikatsiya, standarti diagnostiki ta likuvannya kardiologichnih hvorih / Editors V. M. Kovalenko, M. I. Lutaya, Y. M. Sirenko // Ukraine Association of cardiologists, $2007,128 \mathrm{p}$.

10. Heart rate variability. Standarts of measurement, physiological interpretation and clinical use / Task force of The European Society of Cardiologyand The North American Society of Pacing and Electrophysiology // European Heart Journal. - 1996. - Is. 17. - p. 354-381.

11. Dabrowska B. Parasympathetic Withdrawal Precedes Spontaneous Blood Pressure Elevations in Women with Primary Hypertension / B. Dabrowska, A. Dabrowski [et al.] // Cardiology. - 1996 - Vol.87, Is. 2. p. 119-124. 